To the Editors:

\title{
Variations in the presentation of sickle cell $\beta$ thalassaemia-a report of two cases
}

\section{Introduction}

'Sickle cell disease' encompasses a range of haemoglobinopathies, which result in the formation of sickle haemoglobin $(\mathrm{HbS})$ due to the inheritance of a sickle haemoglobin gene $\left(\beta^{\mathrm{s}}\right)$. It includes sickle cell anaemia $\left(\beta^{\mathrm{s}} \beta^{\mathrm{s}}\right)$, sickle cell trait $\left(\beta \beta^{\mathrm{s}}\right)$ and the many compound heterozygous states of $\beta^{\mathrm{s}}[1]$.Sickle $\beta$ thalassaemia is one such condition. It results from the co-inheritance of a $\beta^{\text {s }}$ gene from one parent and a $\beta$ thalassaemia gene from the other.

This disease runs a variable clinical course. At one end of the spectrum is a crippling haemolytic anaemia, with severe exacerbations, and at the other end is a mild disorder, often found by chance [2,4]. The reasons for these remarkable differences in phenotypic expression are only partly understood. They include the level of fetal haemoglobin $(\mathrm{HbF})$, co-inheritance of $\alpha$ thalassaemia and other genetic variants, climate, and probably of most importance, socioeconomic factors such as the availability of early treatment for infections [3]. We report two cases of sickle $\beta$ thalassaemia with very different phenotypes.

The first patient is a 22-year old girl from Akkaraipattu who presented with episodes of severe bone pain and jaundice since childhood. She was pale, mildly icteric and had moderate splenomegaly. Her parents and only sibling were well. A diagnosis of sickle $\beta^{+}$thalassaemia was made following high performance liquid chromatography (HPLC). A family screen showed her mother and sister to have sickle cell trait, and her father a $\beta$ thalassaemia trait. The patient continues to suffer from recurrent episodes of painful crisis.

The second patient is an 8-year old girl from Ambalanthota who presented with an episode of severe leg pain. She had moderate splenomegaly. Her parents and sibling were well. She too was confirmed as having sickle $\beta^{+}$thalassaemia. Family screening revealed her mother and brother to have sickle cell trait, and her father a $\beta$ thalasaemia trait. Two years after diagnosis, she remains without any significant vaso-occlusive symptoms.

\section{Discussion}

The two patients had very different clinical courses in spite of having the same diagnosis. Both patients had very similar haematological indices (Table 1). Neither required blood transfusion. Why then the difference in the clinical course? A closer look at their genetic make up may have shed some light. However, we feel that a more tangible explanation is available. The only significant difference between the two patients was their socioeconomic status.

Table 1. Red cell indices and haemoglobin quantification results of the two patients

\begin{tabular}{lcc}
\hline & Patient 1 & Patient 2 \\
\hline Red cell indices & & \\
Hb(g/dL) & 8.1 (Low) & 8.9 (Low) \\
RBC(x10 $12 / \mathrm{L})$ & 3.56 & 4.3 \\
MCV(fL) & 71.2 & 64.7 \\
MCH(pg) & 22.6 & 20.7 \\
MCHC(g/dL) & 31.8 & 32.0 \\
RDW(\%) & 18.8 & 20.2 \\
Hb quantification & & \\
HbA (\%) & 4.4 & 4.5 \\
HbA2 (\%) & 8.1 & 7.6 \\
HbF (\%) & 21.1 & 17.7 \\
HbS (\%) & 63.5 & 68.4 \\
\hline
\end{tabular}


Research letters

daughter of two educated parents who were well informed. The second patient with less symptoms was the daughter of the necessity for early and vigorous treatment of even minor infections and prevention of dehydration. They also had a significant financial and geographical advantage over the first family when it came to receiving medical care. The parents of the first patient were physically less able, from a much poorer socioeconomic background and had very little insight with regard to the disease. We therefore stress the importance of socioeconomic factors and proper patient education in the management of patients with sickle cell disease.

\section{References}

1. Bain BJ. Haemoglobinopathy Diagnosis. Oxford: Blackwell science, 2001

2. Weatherall DJ, Genetic disorders of haemoglobin. In: Hoffbrand AV, Lewis SM, Tuddenham EG, eds. Postgraduate Haematology. London: Arnold, 2001: 111-6.

3. Thein SL. Genetic insights into the clinical diversity of $\beta$ thalassaemia. British Journal of Haematology, 2004; 124: 264-74.

4. Wand WC, Lukens JN. Sickle cell anaemia and other sickling syndromes In: Clinical Haematology, 10th ed.USA:Williams \&Wilkins, 1993: 1346-82.

${ }^{1} \mathrm{MN}$ Tudawe, ${ }^{2} \mathrm{NB}$ Senadheera and ${ }^{2} \mathrm{LV}$ Gooneratne, ${ }^{1}$ Consultant Haematologist, ${ }^{2}$ Registrar in Haematology, National Hospital of Sri Lanka, Colombo.

Correspondence: MNT, e-mail: <malant@sltnet.lk> (Competing interests: none declared). Received 5 April 2005 and accepted 27 June 2005. 